\title{
Colleen Cavanaugh: Winner of the Ecology Institute's IRPE PRIZE 1986 in marine ecology
}

\author{
J. Gray* \\ Institutt for Marinbiologi og Limnologi, University of Oslo, Postboks 1064, Blindern, Oslo 3, Norway
}

It is highly unusual that a beginning graduate student develops a fundamental hypothesis which is novel and opposed to accepted ideas, yet which by careful and imaginative research turns out to be correct. Such was the case with Dr. Colleen Cavanaugh.

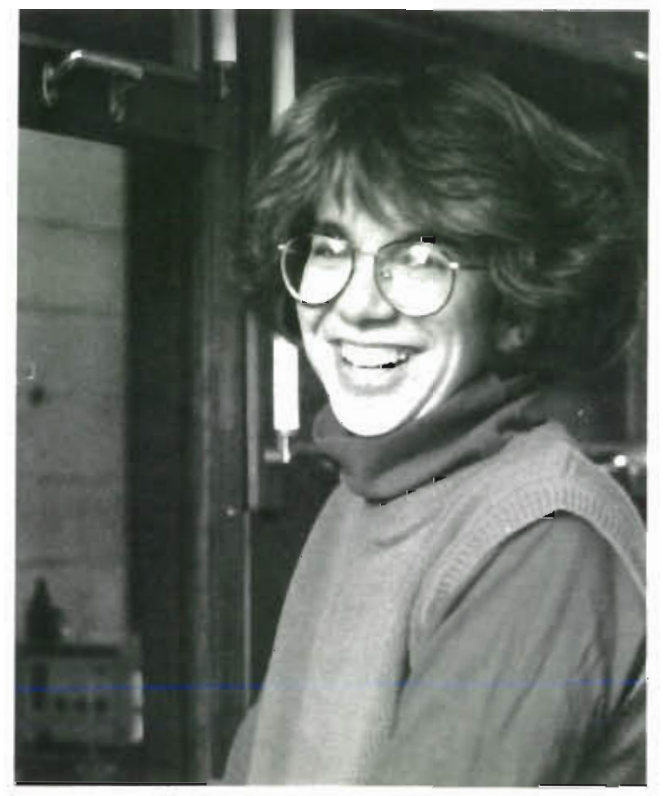

Collen Cavanaugh

Born in Detroit, USA in 1953, Colleen Cavanaugh obtained her B.Sc. degree from the University of Michigan and then moved to Harvard University where she obtained her M. A. and Ph. D. Her initial research involved the King crab Limulus polyphemus but she soon became interested in bacterial mineralisation processes, at first in sediments.

The discovery of the unique fauna of deep-sea hot

\footnotetext{
- Chairman of the Marine Ecology Jury 1985/86 of the Eco-
logy Institute, D-2124 Oldendorf/Luhe, FRG

- Chairman of the Marine Ecology Jury 1985/86 of the Eco-
logy Institute, D-2124 Oldendorf/Luhe, FRG
}

(c) Inter-Research/Printed in F. R. Germany vents by scientists from the Woods Hole Oceanographic Institution (USA), where Colleen Cavanaugh was doing research, excited the international scientific community. One of the most extraordinary finds was the presence at vent sites of an almost $2 \mathrm{~m}$ long species of Pogonophora, Riftia pachyptila. Pogonophora were known from many areas, notably in the deep sea, but as minute thread-like organisms. The remarkable thing about Pogonophora is that they have no gut system. It was presumed that they obtained their nutrition by assimilating dissolved organic material. Colleen Cavanaugh had the revolutionary idea that $B$. pachyptila might in fact be using hydrogen sulphide, which gushes from the hot vents, as an energy source. The idea that organisms associated with hot vents could in fact be relying not on photo- but chemosynthesis as a primary energy source was not one considered reasonable by acknowledged experts. Thus Colleen Cavanaugh had to have great presence of mind to pursue her hypothesis. With enormous skill and application she established ways that her hypothesis could be tested and was soon able to show that $R$. pachytila had symbiotic bacteria packed into its dermal layers. Using a range of techniques she was able to show that the bacteria were chemoautotrophs. This opened up new fields of research, and it is now clear that the organismic assemblage around the vents relies primarily on chemosynthesis as its energy source. The revolutionary nature of these findings can be judged by the fact that Colleen Cavanaugh's first 2 papers were published in Science and Nature respectively.

She appreciated rapidly that organisms living in other habitats where there was a source of sulphur near a source of oxygen could also be deriving a considerable part of their energy from chemosynthesis. Such a habitat is the sulphide layer below oxidised marine sediments described by Fenchel \& Riedl in 1970 (Mar. Biol. 7: 255-268). Colleen Cavanaugh showed that a number of bivalve molluscs, notably Solemya velum, contained symbiotic chemoautotrophic bacteria. Similar findings are now being reported from meiofaunal

$0171-8630 / 86 / 0034 / 0009 / \$ 05.00$ 
oligochaetes and shallow-water Pogonophora and bivalves.

Dr. Cavanaugh has recently returned from a research period at the University of Delft, The Netherlands, where together with Dr. Gijs Kuenen she was isolating, culturing and studying the physiology of sulphuroxidising chemoautotrophic bacteria. This work she will now continue at Harvard University (USA) where she has been awarded a richly deserved Postdoctoral Fellowship.
The Marine Ecology Jury of the Ecology Institute recognises Dr. Cavanaugh's brilliant research, carried out against some opposition from established views, which has opened up new fields of research in microbiology, physiology and the energetics of marine organisms. The Jury were delighted to hear that by chance and good fortune the announcement of the IRPE PRIZE arrived a few days before her wedding - as an additional bonus. 